УДК 78

DOI https://doi.org/10.31723/2524-0447-2021-32-1-3

Катерина Іванівна Єргісва

ORCID: 0000-0001-9710-7557

кандидат мистецтвознавства,

в. о. доцента кафедри спеціального фортепіано

Одеської національної музичної академії імені А. В. Нежданової violenion@gmail.com

\title{
«ОСТРІВ РАДОСТІ» ЯК ПРИКЛАД НОВОЇ СИМВОЛІСТСЬКОЇ ПРОГРАМНОСТІ У ФОРТЕПІАННІЙ ТВОРЧОСТІ К. ДЕБЮССІ
}

Мета роботи - дослідити програмність фортепіанної творчості K. Дебюссі на прикладі «Острова радості». Розглянути вплив нового символістського типу програмності на музичну мову К. Дебюссі та на особливості виконання його фортепіанної музики. Дослідити, як елементи символізму в фортепіанній спадщині К. Дебюссі пов'язані з новаторськими особливостями його музичної мови. Методологія дослідження включає аналітичний, інтерпретативний, історичний, дескриптивний методи. Наукова новизна полягає у формулюванні принципів програмності в фортепіанних творах $K$. Дебюссі, що виявляються завдяки новому розумінню програмного призначення інструментальної («чистої) музики.

Висновки. Доведено, що саме програмність була передумовою поєднання елементів імпресіонізму та символізму в творчості К. Дебюссі, що призвело до корінних змін у самій природі музичної програмності. Розглянуто три основні історичні типи музичної програмності: ситуативно-прикладний, автономно-інтерпретуючий та символістський (метаконтекстуальний). Виявлено, що авторський підхід К. Дебюссі до феномена програмності поєднує ознаки автономно-інтерпретуючого та символістського типів програмності. Розкрито символічне значення назви твору К. Дебюссі «Острів радості» та зв'язок художнього змісту иього твору з ідеями філософії життя. Доведена необхідність використання агітуючого типу дискурсу в процесі виконання «Острову радості». Розглянуті засоби виразності, які застосовуються у цьому творі та пов'язані з новою символістською програмністю, як композиторські (контонаційність, поліладовість, нові принципи формоутворення, монтажний принцип організації музичного матеріалу, фонічність, фоновий тематизм), так і виконавські (особливості звуковидобування, артикуляції, педалізації, динамічні контрасти тощо). Підкреслюється необхідність стану ігрової спонтанності, імпровіза-

(C) Єргієва К. I., 2021 
ційності у виконанні фортепіанних творів К. Дебюссі, зокрема «Острову радості».

Ключові слова: символістський тип програмності, фонічність, арабеска.

Yerhiieva Kateryna Ivanivna, PhD in Arts, Acting Associate Professor at the Department of Special Piano of the Odesa National A. V. Nezhdanova Academy of Music

"The Island of Joy" as an example of a new symbolic programmaticity in piano works of C. Debussy

Research objective. The aim of the work is to study the programmatic nature of C. Debussy's piano works on the example of "The Island of Joy". To consider the influence of the new symbolic type of programmaticity on the musical language of $C$. Debussy and on the peculiarities of his piano music performance. Study how the elements of symbolism in the piano heritage of C. Debussy are related to the innovative features of his musical language. The methodology of the research is based on the analytical, interpretive, historical, descriptive methods. The scientific novelty lies in the formulation of the principles of programmaticity in the piano works of C. Debussy, which are manifested through a new understanding of the program purpose of instrumental ("pure") music.

Conclusions. It is proved that programmaticity was a prerequisite for combining elements of impressionism and symbolism in the work of C. Debussy, which led to fundamental changes in the very nature of musical programmaticity. Three main historical types of musical programmaticity are considered: situational-applied, autonomous-interpretive and symbolic (metacontextual). It is revealed that the author's approach of C. Debussy to the phenomenon of programmaticity combines the features of autonomousinterpretive and symbolic types. The symbolic meaning of the title of $C$. Debussy's work "The Island of Joy" and the connection of the artistic content of this work with the ideas of the philosophy of life are revealed. The necessity of using the agitative type of discourse in the process of performing "The Island of Joy" is proved. The means of expression used in this work and related to the new symbolic programmaticity are considered - both compositional (contonationality, polylade, new principles of shaping, montage principle of organization of musical material, phonicity, background thematicism) and performative (features of sound production, articulation, pedaling, dynamic contrasts, etc.). The necessity of the state of playful spontaneity, improvisation in the performance of piano works by $C$. Debussy, in particular "The Island of Joy", is emphasized.

Key words: symbolic type of programmaticity, phonicity, arabesque.

Актуальність теми дослідження зумовлена необхідністю більш глибокого розуміння фортепіанної спадщини К. Дебюссі як новаторської, яка стала певною мірою засадничою для нових творчих парадигм XX-XXI століть. 
Мета дослідження - розширити розуміння змісту програмної музики К. Дебюссі для фортепіано (на прикладі «Острова радості»).

Наукова новизна полягає в тому, що програмність у фортепіанній творчості К. Дебюссі розглядається як заснована на принципово новому, символістському розумінні програмного призначення музики.

Виклад основного матеріалу. Прийнято вважати, що К. Дебюссі є видатним представником музичного імпресіонізму. Однак застосування до музики цього композитора аналогій $з$ імпресіоністським живописом істотно збіднює сприйняття його творчості і не дозволяе цілком оцінити новаторство його ідей. У музиці К. Дебюссі нарівні з гармонією, мелодією, ритмом важливу роль грав сам фортепіанний звук, фортепіанна сонорика (специфічна темброзвучність інструменту фортепіано). Однак особливі звукові якості його музики не можна розглядати лише як прояв «звукової колористики», вторинний стосовно гармонійних особливостей його стилю.

У культурному просторі, в якому жив і творив К. Дебюссі, на зміну імпресіонізму прийшли нові течії: символізм, експресіонізм, неокласицизм, ін. Однак сучасники розглядали творчість цього композитора як прояв імпресіонізму, який тоді (початок XX ст.) вже перестав відігравати провідну («авангардну») роль у мистецтві, хоча імпресіоністичні музичні твори не втрачали популярності у публіки.

На думку С. Яроцинського, в тій мистецькій добі з'явилася «Помилкова думка про відставання музики від інших мистецтв - відставання, яке не міг надолужити навіть такий художник, як Дебюссі» [10, с. 87].

Насправді, відставало саме музикознавство, тому що старі структури (форми) музичного твору та його символіки, музична мова, ін. будувалися за іншими принципами i тому на перший погляд були незрозумілими ортодоксам і традиціоналістам.

Багато сучасників К. Дебюссі відчували, що рамки імпресіонізму занадто вузькі для творчості цього композитора: П. Дюка, Р. Годе, Ж. Жан-Обрі, Л. Лалуа, і сам К. Дебюссі, який писав, що «намагається робити в деякому роді реальності - те, що дурні називають «імпресіонізмом», терміном 
настільки погано вживаним, як тільки можливо, особливо критиками мистецтва» [3, с. 526].

Л. Фабіан у своїй великій монографії, присвяченій композитору, хотів, як і Л. Лалуа, довести, що музика К. Дебюссі, «символістська по духу і імпресіоністична по техніці», прагне до «абсолютної», «чистої» музики і веде до «неокласицистичної» епохи [12, с. 258].

Оскільки К. Дебюссі вважав, що «музика створена для невимовного» [2, с. 384], предметом його програмних інтересів були саме ті сторони людського пізнання, які можуть бути виражені лише за допомогою символів, тобто символічним шляхом.

Отже, саме використання програмних можливостей музики стало для К. Дебюссі сполучною ланкою між імпресіонізмом і символізмом. У результаті такого переходу докорінно змінилася сама природа музичної програмності.

Якщо розглядати програмну функцію музики з точки зору іiі історичного розвитку, то перший тип програмності можна визначити як ситуативно-прикладний, зумовлений переважною первинно-жанровою будовою музики і їі ритуально-прагматичними функціями, зовнішніми факторами формування музично-смислового змісту, безпосередньою залежністю від соціокультурних домінант.

Другим історичним типом програмності стає автономно-інтерпретуючий, який, з одного боку, конкретизує і в цій якості звужує образне призначення музичного звучання, 3 іншого боку, розширює специфічні способи музичного формоутворення, можливості музичної логіки і семантики як вторинно-авторські.

Якщо межа між першим і другим типами «програмного традиціоналізму» пролягає в досвіді культури пізнього Відродження і бароко (а для вітчизняної музики дещо пізніше, в період освоєння європейських класицистичних норм), то зміна другого типу третім постає як закономірний підсумок еволюції романтичного методу і викликаних нею активних стильових новацій на рубежі XIX-XX століть.

Tретій історичний тип програмності можна назвати метаконтекстуальним, або символістським. Саме перехід до нього, надання йому значення стійкої риси музичної поетики є одним з головних напрямів стильових новацій K. Дебюссі. Програмний метод К. Дебюссі у світлі наве- 
деної типології постає перехідним, що з'єднує ознаки другого i третього типів «програмного коментування» музики.

Така перехідність, на наш погляд, і заважає С. Яроцинському зарахувати К. Дебюссі до символістів, але змушує спеціально обговорювати «символічні елементи» його музики.

У творчості К. Дебюссі словесні позначення не обмежують розуміння музики, а навпаки, виявляють ii смислову безмежність.

Показовою в цьому відношенні є назва п’єси «Острів радості». Саме поняття «острів» має глибоко символічний характер. На думку Д. Трессідера, символіка цього поняття походить від індуїстської традиції, згідно з якою острів - це «образ духовного світу в хаосі матеріального існування» [8].

Символ острова часто трапляється в міфології різних народів, у творах різних напрямів мистецтва як у музиці, так і в живописі, в літературі.

Як відомо, «Острів радості» був натхненний картиною А. Ватто «Відплиття на острів Цитеру», де зображено світське суспільство: витончені дами і кавалери, що спускаються до прикрашених човнів, готових відвезти їх на острів кохання (Цитера - одна з назв богині Венери).

Острів Цитери в європейській культурній традиції - це ідея, символ блаженства, насолоди. Залишаючись символом, загальним для всіх, нікого не залишаючи байдужим, «Острів радості» для кожного виконавця, для кожного слухача - інтерпретатора ("Нomo interpretatus" за теорією Ю. Ніколаєвської) стає своїм, неповторним, втілюється по-новому в кожному наступному виконанні-інтерпретації.

У творчості К. Дебюссі відбилося його сприйняття та інтерпретація музичного твору (а також будь-якого твору мистецтва) як невичерпного у смисловому плані. Про це свідчить фраза в одному з його листів: «Ви справді думаєте, що вірш має лише один сенс? Хіба ви не знаєте, що кожен ваш вірш трансформується у разі прочитання кожним з читачів? Подібне відбувається і з кожним музичним текстом. <..> Все відносно» [13].

Авторка цієї статті неодноразово виконувала «Острів радості». Справді, під час кожного виконання в уяві виникають нові картини. Але завжди інваріантним залишається 
використання авторкою агітуючого типу дискурсу в процесі виконання цього твору.

Основною інтенцією, головною ідеєю «Острову радості» $є$ заклик до усвідомлення слухачами справжнього, екзистенційного смислу життя, від якого часто відволікають буттєві турботи та тривоги. Це заклик, сповнений насолодою від кожного моменту життя, радістю від самої можливості жити на цьому світі, любові до оточуючого нас світу. Недарма, за спогадами М. Лонг, сам композитор хотів, щоб вступ твору звучав «як заклик» [4, с. 61].

У цьому вступі криється потужна енергія, яка поступово, протягом усього твору набирає сили, але має підкорятися волі виконавця завдяки точності ритму. Ця енергія яскраво проривається «на свободу» лише у фінальній кульмінації, викликаючи почуття безмежної радості, немов від споглядання сходу сонця, яке своїм світлом перемагає, розсіює чаклунські чари.

Ритм як засіб художньої виразності в «Острові радості» відіграє також дуже важливу роль у створенні ілюзії спонтанності, гри, який був притаманний творчості К. Дебюссі загалом і без якого було б неможливо передати почуття радості зокрема.

Це виражається насамперед в орієнтації композитора на танцювальність, на комбінаторну гру різними танцювальними жанрами (головна тема поєднує жваву пунктирну ритміку та елементи тарантели, які плавно перетікають у жигу в партії правої руки і ритми хабанери в партії лівої руки).

У цьому творі К. Дебюссі яскраво відображені ідеї ствердження бурхливої і нестримної життєвої енергії, задоволення від процесу розвитку, становлення, зростання.

Ці ідеї перегукуються з популярною на рубежі XIX-XX ст. філософією життя, зокрема 3 філософськими поглядами яскравого іiі представника А. Бергсона, основні принципи яких багато в чому схожі з ідеями символізму. Цей філософ надавав велику важливість інтуїції та спонтанності. Він проявляв великий інтерес до творчості К. Дебюссі і підкреслював зв'язок його музики і своїх філософських пошуків.

Символістська програмність, до якої спрямована творчість К. Дебюссі, відображаючи світогляд композитора і дух епохи, в якій він жив, веде до глобального переосмислення уявлень про гармонію, артикуляцію, динаміку, принципи 
формоутворення, логіку побудови мелодійної лінії і фактурно-гармонійного розвитку тощо.

Так, у гармонійній мові К. Дебюссі відчуття безпосередності в сприйнятті Буття у всьому його різноманітті, смислової багатовимірності проявляється в таких новаторських рішеннях, як цінність кожного співзвуччя (контонаційність), ослаблення ладофункціональних, вводнотонових відносин, акордові паралелізми та поліладовість. В «Острові радості» композитор використовує ці прийоми в репризі головної теми, змішуючи лідоміксолідійський і целотоновий лади.

Шо стосується принципів формоутворення, то, як відомо, К. Дебюссі вважав, що музику «по самій іiі сутності не можна відливати в строгі і закінчені форми» [1, с. 130].

Цей видатний композитор був першим, хто цілеспрямовано порушив класико-романтичні закони формоутворення. На зміну лінійній логіці і детермінізму приходить спонтанно організована композиція, як би відкрита назустріч творчому хаосу, «вселенській потенційності» (В. Налімов), завдяки чому виникає смислова багатовимірність.

Такий нелінійний підхід до формоутворення перегукується 3 ідеями А. Бергсона про «час-винахід». Як пише Е. Ровенко, «в музиці Дебюссі temps-invention вступає у свої права на етапі імпровізаційного пошуку звукового еквівалента початкового уявлення про форму цілого і загальний план композиції» [6].

Показова у цьому відношенні і форма «Острову радості», яка вражає поєднанням абсолютної стрункості і логічності зі свободою висловлювання, природністю течії музики. В образному відношенні це викликає асоціацію з човном, якого начебто самого тягне, несе течією до острова, а весляру (виконавцю) залишається тільки віддатися у владу цього потоку.

Відображенням символістської ідеї про «чисте мистецтво», поняття Невимовного, непізнаваної Ідеї в творчості К. Дебюссі служать арабески - вільні мелодійні лінії, які не базуються на мотивно-тематичному розвитку. За допомогою арабески стирається грань між темою і фігурацією. Завдяки ритму, регістровці, артикуляції арабеска може як бути на передньому плані, так і відійти на задній план, один і той же хід може використовуватися і як тема, і як фігурація. 
Наприклад, в «Острові радості» в тт. 9-11:

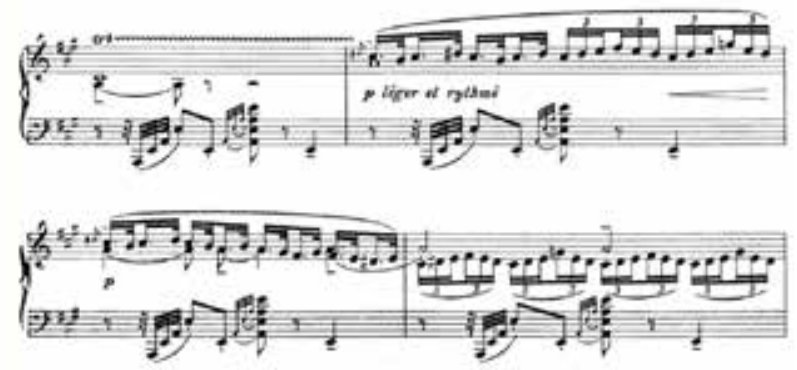

Б. Сгорова розглядає арабеску в творчості К. Дебюссі як головну ознаку його зв'язку зі стильовим напрямом Art Nouveau, в основі якого лежить «філософія життя». Сам композитор трактує арабеску як універсальну естетичну категорію, що з'єднує мистецтво і природу: «фундаментальний принцип, який об'єднує всі мистецтва, з одного боку, та підкоряє їх законам краси, що входять у всеосяжні закони природи, - з іншого» [7].

Справді, переважання фонового тематизму над мелодійним $є$ відображенням неантропоцентричної позиції, злиття індивідуально-особистісного начала із загальним, Абсолютом.

Велике значення фонічності в фортепіанних творах К. Дебюссі також проявляється в частому використанні гри через руку. Це необхідно, коли тематична репліка звучить вище фонової фігурації, щоб зберегти ритмічну та динамічну рівність фону. Цей прийом досить часто використовується в «Острові радості» (тт. 20-24):

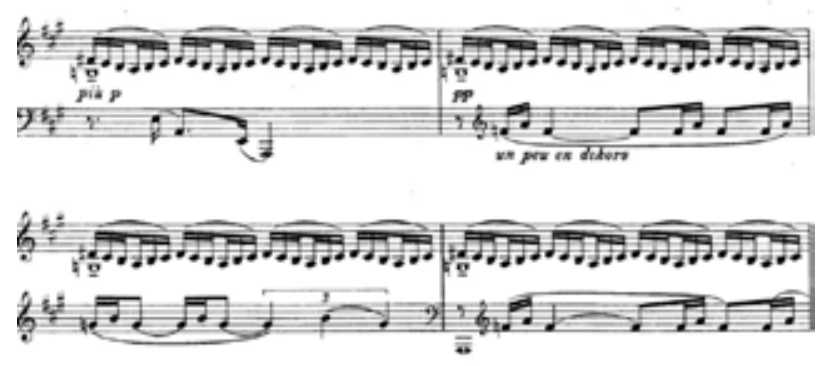


Такий приклад також демонструє роль фонічного ефекту просторовості в фортепіанній творчості композитора, оскільки бас знаходиться на великій відстані від інших голосів. Завдяки такому поляризованому звучанню, а також за рахунок хиткої, невизначеної гармонії виникає відчуття таємничості, багатозначності, а верхній голос звучить більш експресивно.

Втілення численних фонічних ефектів у творах К. Дебюссі для фортепіано неможливо без педалі. Сам Дебюссі досконало володів педаллю і у своїх творах досягав 3 iіi допомогою неповторних звукових ефектів. За його словами, він прагнув «робити з педалі щось на зразок дихання» $[11$, c. 150$]$.

Зокрема, безпосередньо пов'язаний з мистецтвом педалізації ефект обертонового резонансу, що подовжує звучання великих тривалостей. Наприклад, у тт. 64-65 «Острова радості»:

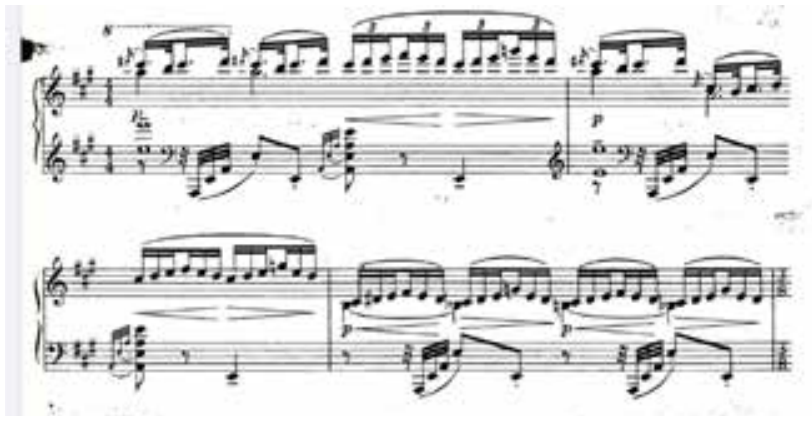

У зазначеному прикладі немає можливості утримувати руками цілі тривалості; вони тримаються за допомогою правильного звуковидобування, педалі та обертонового резонансу.

Важливу роль у музичній мові К. Дебюссі грає цілотонний лад. В «Острові радості» композитор трактує його по-різному. Так, епізод, заснований на висхідних цілотонних ходах (починаючи 3 т. 115) наштовхує на асоціації 3 чаклунськими заклинаннями, магічними ритуалами: 


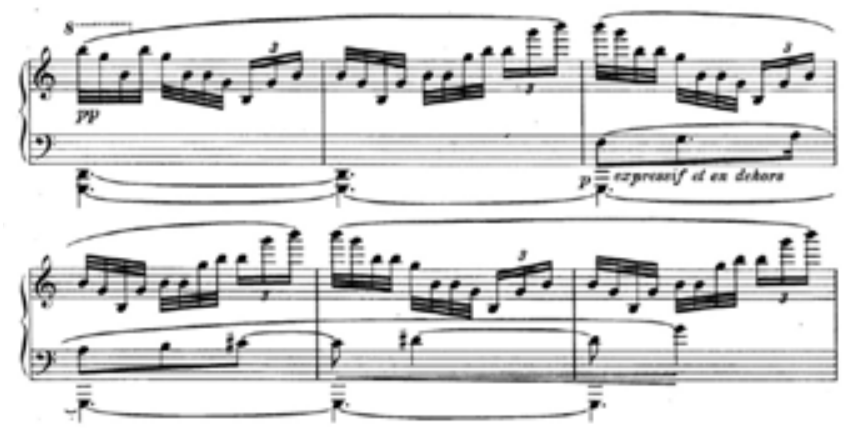

А в тт. 182-185 на цілотонному ладі побудована яскрава кульмінація. Бурхливі арфообразні спадні пасажі зливаються в єдину сонорно-ущільнену вертикаль і ніби «змивають» передуючу їм ману, томління:

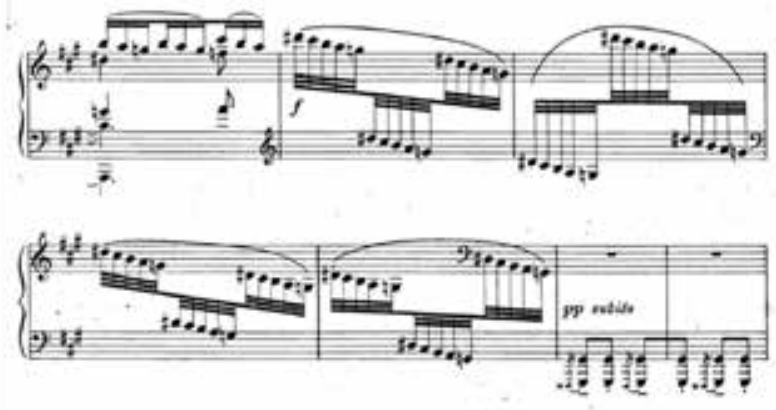

Перехід від целотонних пасажів до октав у басовому регістрі супроводжується різким перемиканням динаміки $3 f$ на $p p$. Такий прийом часто використовується композитором і пов'язаний зазвичай зі зміною фактури, регістру, несподіваною модуляцією в далеку тональність і т. П. Подібні різкі динамічні контрасти являють собою непросту задачу для виконавця. Вони несумісні 3 надмірною завченістю, «закостенілістю» інтерпретування. Щоб повною мірою передати ці контрасти, необхідно перебувати у стані ігрової спонтанності, імпровізаційності. 
Подібна гра фарб, кольорів поряд з музично-тематичною арабескою набувають у фортепіанній музиці К. Дебюссі образно-символічне призначення.

У музиці К. Дебюссі немає образних конфліктів, переважає гра світло-тіней. Перехід арабески від теми до фігурації - це відображення тіньового контуру того, що раніше було яскраво освітлене. Різкі перемикання між контрастними епізодами втілюють не конфліктний, а монтажний принцип організації музичної драматургії. Подібного роду прийоми відображають амбівалентність, а іноді і багатозначність світу і відносин з ним людини.

У творах К. Дебюссі відсутні негативні емоції, критицизм, оціночне судження як таке. У цьому його творчість перегукується з ідеями ще одного знаменитого представника філософії життя - Ф. Ніцше, який писав, що «мораль - це зазнайство людини перед природою».

На цій підставі можна стверджувати, що відсутність моралізаторства, оціночних суджень стає частиною світогляду К. Дебюссі, передбачивши постмодернізм кінця XX ст. і мультикультуралізм початку XXI ст., як форма (і необхідна умова) співіснування у сучасному полікультурному світі.

Якщо композитори епохи класицизму намагалися відобразити в музиці об'єктивне буття, а романтики - розкрити внутрішній світ людини, іiї суб'єктивні переживання, то К. Дебюссі прагнув своєю музикою об'єднати людей один 3 одним і з навколишнім світом, природою. 3 одного боку, він не нав'язує ніяких суб'єктивних оцінок, проявляючи таким чином об'єктивність у творчості як характерну тенденцію для мистецтва XX століття. I разом з тим він передає музикою своє переживання істини.

Нова символістська програмність відкриває внутрішні концептуальні можливості музики, тобто вона розвивається зсередини зовні, від специфічних семантичних властивостей музичного тексту до їх визначення вже за межами такого тексту. Тобто символістська програма вже цілком належить самій музиці, і це оголошується, декларується символістами, як композиторами, так і поетами. Так. П. Валері писав: «Те, що було охрещене ім'ям «символізм», зводиться до спільного для численної плеяди поетів наміру відібрати у музики те, що їм має належати» [14, с. 97]. 
Висновки. Таким чином, «Острів радості» $є$ яскравим втіленням принципів нової символістської програмності в фортепіанній творчості К. Дебюссі.

Потрапляючи на острів, герої як у міфології, так і в літературі зазвичай переживають глобальні зміни у свідомості, світогляді. У геніальному творі К. Дебюссі символ острова «входить у резонанс» 3 поняттям радості, яка, згідно з А. Бергсоном, приголомшує душу до самих іiї основ, завдяки чому душа «переживає містичне перетворення» [9].

«Острів радості» вражає своєю іскрометністю, викликаючи в світогляді слухача незворотні зміни, навчаючи радіти життю і по-справжньому цінувати його.

\section{СПИСОК ЛІТЕРАТУРИ} $286 \mathrm{c}$.

1. Дебюсси К. Избранные письма. Ленинград : Музыка, 1986.

2. Кокорева Л.М. Клод Дебюсси: Исследование. Москва : Музыка, 2010. 496 с.

3. Кремлёв Ю.А. Клод Дебюсси. Москва : Музыка, 1965. 792 с.

4. Лонг М. За роялем с Дебюсси. Москва : Сов. композитор, 1985. $158 \mathrm{c}$.

5. Ніколаєвська Ю.В. Музична комунікація як інтерпретативний феномен (на прикладі творчості XX - початку XXI ст.) : дис. ... докт. мистецтвознав. : 17.00.03. Одеська нац. муз. акад. ім. А.В. Нежданової. Одеса, 2021. 517 с.

6. Ровенко Е.В. Время в философском и художественном мышлении. Анри Бергсон, Клод Дебюсси, Одилон Редон. URL: https://books.google.com.ua (дата звернення: 09.02.2021).

7. Перич О.В. Р. Вагнер и К. Дебюсси: к вопросу о мифологических основах творчества. URL: https://cyberleninka.ru/article/n/rvagner-i-k-debyussi-k-voprosu-o-mifologicheskih-osnovah-tvorchestva/ viewer (дата звернення: 02.03.2021).

8. Трессидер Д. Словарь символов. URL: https://www.gumer.info/ bibliotek_Buks/Culture/JekTresidder/408.php (дата звернення: 02.03.2021).

9. Ямпольская А. О радости: Бергсон и Янкелевич. URL: https://cyberleninka.ru/article/n/o-radosti-bergson-i-yankelevich/viewer (дата звернення: 02.03.2021).

10. Яроцинский С. Дебюсси, импрессионизм и символизм. Москва : Прогресс, 1978. 232 с.

11. Debussy C. Lettres a son editeur. Paris : A. Durand et fils, 1927. 190 p.

12. Liess A. Claude Debussy. Strassburg: Heitz, 1936. 427 p.

13. Djupdal K. Debussy at the piano. URL: http://www.djupdal.org/ karstein/debussy/ (дата звернення:

14. Valery, P. Variety. Paris: NRF, 1924 [in French]. 


\section{REFERENCES}

1. Debussy. Selected Letters. Leningrad: Music, 1986 [in Russian].

2. Kokoreva, L.M. Claude Debussy: Research. Moscow: Music, 2010 [in Russian].

3. Kremlev, Yu.A. Claude Debussy. Moscow: Music, 1965 [in Russian].

4. Long, M. At the piano with Debussy. Moscow: Sov. Composer, 1985 [in Russian].

5. Nikolayevska, Y.V. Musical communication as an interpretive phenomenon (based on the creative work of the 20th - early 21st centuries). Doctor's thesis. Odesa: ONMA imeni A.V. Nezhdanovoi, 2021 [in Ukrainian].

6. Rovenko, E.V. Time in philosophical and artistic thinking. Henri Bergson, Claude Debussy, Odilon Redon. Retrieved from: https://books.google.com.ua [in Russian].

7. Perich, O.V. R. Wagner and K. Debussy: to the question of the mythological foundations of creativity. Retrieved from: https://cyberleninka. $\mathrm{ru} /$ article/n/r-vagner-i-k-debyussi-k-voprosu-o-mifologicheskih-osnovahtvorchestva/viewer [in Russian].

8. Tressider, D. Dictionary of symbols. Retrieved from: https://www.gumer.info/bibliotek_Buks/Culture/JekTresidder/408.php [in Russian].

9. Yampolskaya, A. About joy: Bergson and Yankelevich. Retrieved from: https://cyberleninka.ru/article/n/o-radosti-bergson-i-yankelevich/ viewer [in Russian].

10. Jarocinsky, S. Debussy, impressionism and symbolism. Moscow: Progress, 1978 [in Russian].

11. Debussy, C. Letters to his editor. Paris: A. Durand et fils, 1927 [in French].

12. Liess, A. Claude Debussy. Strassburg: Heitz, 1936 [in German].

13. Djupdal, K. Debussy at the piano. Retrieved from: http://www.djupdal.org/karstein/debussy/ [in English].

14. Valery, P. Variety. Paris: NRF, 1924 [in French]. 